\title{
A PHILIPPINE NEMESTRINID (DIPTERA)
}

\author{
By Charles S. Banks
}

Chief, Division of Entomology, Bureau of Science, Manila

\section{ONE PLATE}

That a family of insects, containing representatives so large and so conspicuous both in coloring and habits as the Nemestrinidæ, should have escaped the attention of collectors in these Islands is certainly one of the best evidences of the vagaries of natural-history exploration. However, the fact that no member of this family has been hitherto reported from the Philippines is not so remarkable in the light of the further fact that since Kertész's ${ }^{1}$ work was published in 1909 , but eight species in five genera, one of which is new, have been described from the Oriental region: three from Ceylon, one from Formosa, one from New Guinea, and three from Australia. Two of the species from Ceylon and the one from Formosa belong to the genus which has come to light in the Philippine Islands, namely Hirmoneura. That other species of this genus will be found in the Philippines is almost certain, since it is now known to be distributed through from Australia to Formosa along what we may term a natural bridge. We should likewise expect to find members of the closely related genera: Trichopthalmus, most of the species of which are from Australia but so far only reported from that country, Tasmania, and Chile, with one doubtful African record, and Atriadops reported from Sumatra, Java, and China in addition to a single species recorded from Africa.

The species here recorded is described as new, its characteristics being quite unlike those of any species noted from this region, in fact it bears little resemblance to any other member of the genus, especially in size.

The type specimen was taken by me in a clearing in rather dense forest on a bright day in June, flying near the ground much after the fashion of the Bombylidæ. It was at first supposed to be a member of this family, and it was only when the

${ }^{1}$ Kertész, Cat. Dipt. hucus. Deser., Budapestini 4 (1909) 22-32. $181287-9$ 
specimens in the Bureau of Science were being sorted that its true nature was discoverd, with considerable surprise, it must be admitted. Had I at the time realized what a real treasure it was, I should have been on the alert for more specimens. As it is, we have but a single male, intact, but with much of the pubescence worn from the notum and tergum.

Hirmoneura philippina sp. nov.

Male large, robust, brown, pubescent, legs brownish yellow, with coarse, adpressed auburn pile; wings uniformly semiopaque brown, each longer than body.

Head wider than thorax, slightly more than hemispherical, nearly holoptic, the face and vertex one-seventh of the headwidth, sides of vertex converging slightly caudad in region of ocelli (Plate 1, fig. 3) ; eyes bare, red-brown with garnet reflections, occupying nearly whole of head in profile; occiput slightly convex near eye margins, dark tawny, pilose; ocelli placed on two prominent tubercles separated by a shallow, wide, transverse sulcus, the anterior ocellus at cephalic margin of anterior tubercle, each posterior ocellus at lateral margin of posterior tubercle and contiguous with eye (Plate 1, fig. 3 ) ; vertex from region of ocellus, and face to buccal cavity bisinuous in profile and with black and tawny, semierect, silky hairs growing more tawny at antennæ and continuing shorter along lateral margins of buccal cavity (Plate 1, fig. 1).

Antennæ stout, tawny, covered with heavy, tawny to golden bristles proximad, rather bare distad; of seven segments, first oval, three times length of second which is concave distad to receive segment 3 , the latter being one-third longer and very broadly and bluntly fusiform; segments 4 to 7 form the style which is as long as segments 1 to 3 together, segments 4 to 6 tawny, 7 opaque black-brown; segment 1 with heavy, tawny bristles, 2 with fewer scattered ones and 3 with an equatorial row of about seven stout black setæ in addition to a very fine, closely adpressed golden pile; segments of style finely pubescent (Plate 1, fig. 5).

Palpi reddish tawny, long, erect, partially concealed in longitudinal sulci close to eye-margins, first segment subarcuate, second sinuate, slender, five-ninths length of first, entire palpus twice length of antenna excluding style, geniculate at base, strongly hairy on anterior margin, no hairs basad, hairs semierect, those on second segment pointing proximad (Plate 1, fig. 4). 
Labellæ wide and flat with circular, naked margins, proboscis slightly chitinized, dark brown, somewhat shrivelled in this specimen (Plate 1, figs. 1 and 2).

Thorax compactly subquadrate, mesonotum convex with a transverse sulcus on caudal third, pilosity crenulate, worn on notum except laterad, where it is golden, a tuft of golden pile on mesopleuron cephalad of spiracle and another caudad of wingbase; scutellum lenticular, transversely striate, its lateral margins circularly excised, its caudal margin with a broad elevated callosity, a fine crenulate golden pile just caudad of its margin on metanotum (Plate 1, fig. 6) ; abdomen as long as head and thorax, broadly oval in outline, segmentation prominent by reason of inflation of interstitial membranes; tergites brownish yellow, glabrous and with fine, black, scant, adpressed pile, worn off in patches, sternites as tergites, but paler glabrous and with much scantier pile; interstitial membranes with black pile; genitalia prominent, glabrous, brown (Plate 1, figs. 8 and 9).

Legs normal, fore femora nearly as long as tibiæ and tarsi, mid femora slightly longer, hind femora as long as hind tibiæ, all pale rufous brown with uniform, coarse, reddish brown or auburn pile, hind tarsi swollen basad and curved (Plate 1, fig. 7) ; fore and mid femora paler.

Wings uniformly shaped and typically veined, longer than entire body, of a uniform pale, semiopaque brown, veins only slightly darker and more opaque. Halteres gray buff with black knobs.

Length, 17.5 millimeters; width of thorax, 4.75 ; length of wing, 20 , width, 5 .

Type, male, No. 18619, in entomological collection, Bureau of Science, Manila.

Mindana0, Lanao, Kolambugan, Latitude $8^{\circ} 10^{\prime}$ north, longitude $123^{\circ} 55^{\prime}$ east. June 15,1914 , Charles S. Banks.

This species falls naturally with $H$. annandalei Licht., and $H$. basalis Licht., because of its bare eyes, there being not a vestige of pubescence, even under the microscope. From $H$. annandalei it differs in size, in the color of the hairs, there being no "yellowish" abdominal hairs, in the color of legs and wings and in width of vertex and frons with respect to eye width.

Another remarkable thing concerning this insect is that it was taken at sea level in latitude $8^{\circ} 10^{\prime}$ north, while those species recorded from British India come from altitudes of from 3,000 to 9,000 feet, about 1,000 to 3,000 meters. 
Hirmoneura philippina adds another link in the chain of evidence of a former strong connection between Australia and the Asiatic continent through the Philippines and Formosa. I have little doubt that other species, perhaps in other genera of this interesting and little-known family will be found, not only in Mindanao, but likewise in northern Luzon, perhaps in the mountainous regions.

\section{LITERATURE CONSULTED}

MACQUART, J. Diptères exotiques nouveaux ou peu connus, Parts I, II, and Suppl. 1-5 (1838-1855).

BRAUER, E. Zwei Parasiten der Rhizotrogus solstitialis aus der Ordnung der Dipteren, mit 2 Tafeln. Sitzungsberichte der MathematischNaturwissenschaftlichen Classe der Kaiserlichen Academie der Wis. senschaften, Abteilung I, 88 (1883) 865 et seq., pl. 1.

Kertész, C. Catalogus Dipterorum Hucusque Descriptorum Museum Nationale Hungaricum, Budapestini 4 (1909) 22 et seq.

LICHTWARDT, B. Beitrag zur Kenntnis der Nemestriniden. Deutsche Entomologische Zeitschrift, Teile I bis V, mit Textfiguren (1909) 113, 507, 643; (1910) 371, 589.

LiCHTWARDT, B. Nemestriniden (Dipt.) aus dem Indian Museum in Calcutta, Records of the Indian Museum 9 (1913) 333 et seq.

BRunetTi, E. Nemestrinidae; Fauna of British India, Diptera Brachycera 1 (1920) 144 et seq. 


\section{ILLUSTRATION}

[Drawn by the author and Macario Ligaya.]

Plate 1. Hirmoneura philippina sp. nov.

Fig. 1. Head, profile, showing palpus extruded from its groove; $\times 8.5$.

2. Head, cephalic, view, proboscis half extruded; $\times 8.5$.

3. Head, dorsal view, showing ocelli and occiput; $\times 8.5$.

4. Right palpus, position when at rest; $\times 20$.

5. Right antenna, showing three of seven spines on third segment; $\times 35$.

6. Mesonotum and scutellum of thorax, with wing bases and halteres; $\times 8.5$.

7. Tarsus of right hind leg, showing curved first tarsal segment, pulvillus, and unguis; $\times 24$.

8. Abdomen, profile of caudal segments, showing genitalia, including lateral claspers and recurved ventral claspers; $\times 8.5$.

9. Abdomen, caudal view of genitalia, showing dorsal and ventral claspers between which is seen the penis; $\times 8.5$. 


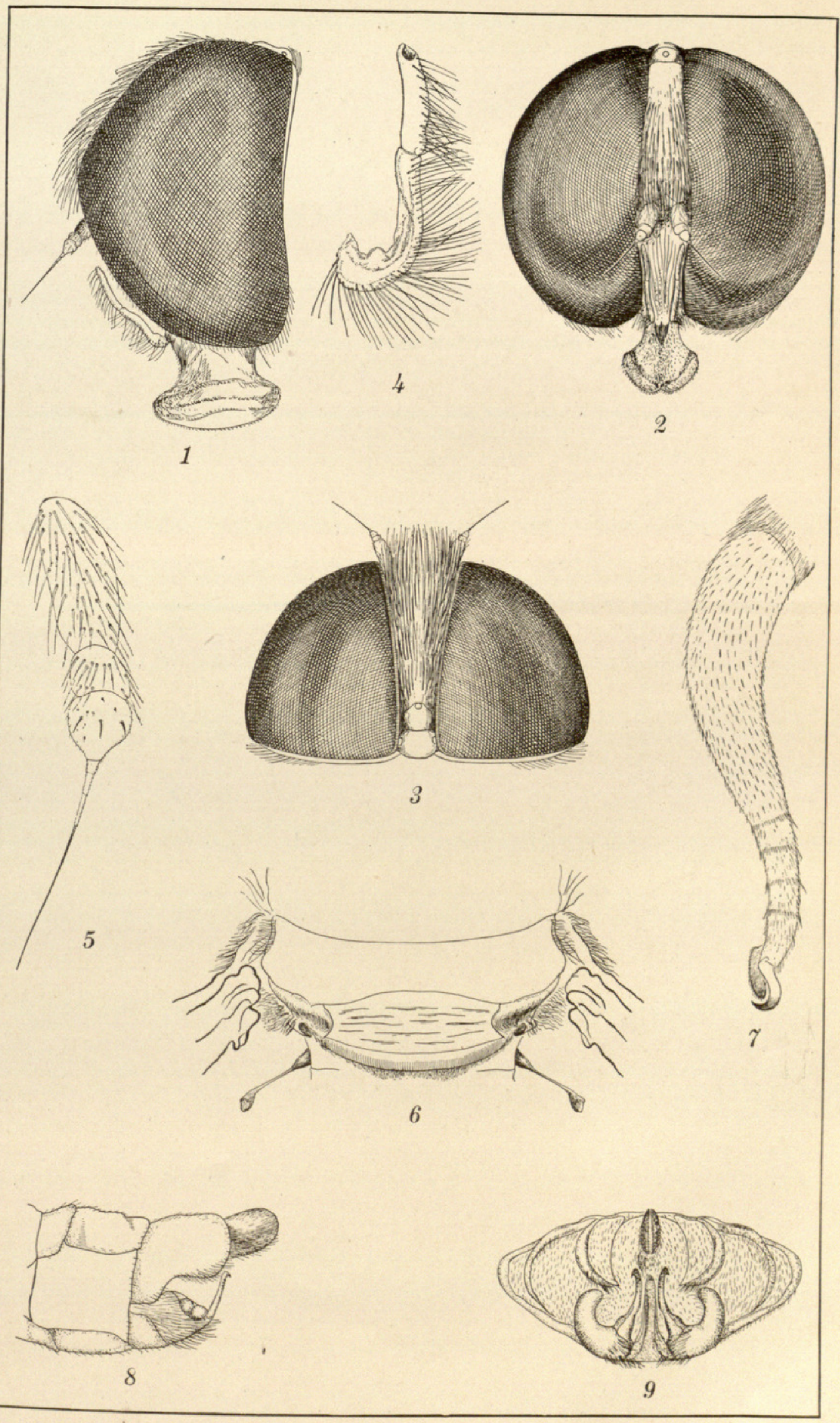

PLATE 1. HIRMONEURA PHILIPPINA SP. NOV. 


\section{$2 \mathrm{BHL}$ Biodiversity Heritage Library}

Banks, Charles S. 1922. "A Philippine Nemestrinid (Diptera)." The Philippine journal of science 19, 517-521. https://doi.org/10.5962/bhl.part.1234.

View This Item Online: https://www.biodiversitylibrary.org/item/1129

DOI: https://doi.org/10.5962/bhl.part.1234

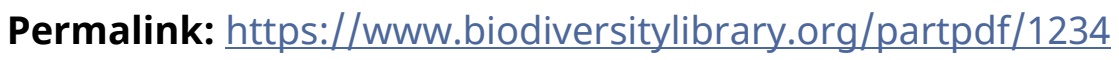

\section{Holding Institution}

Missouri Botanical Garden, Peter H. Raven Library

\section{Sponsored by}

Missouri Botanical Garden

\section{Copyright \& Reuse}

Copyright Status: Public domain. The BHL considers that this work is no longer under copyright protection.

This document was created from content at the Biodiversity Heritage Library, the world's largest open access digital library for biodiversity literature and archives. Visit BHL at https://www.biodiversitylibrary.org. 